DOI 10. 18307/2017. 0209

(c) 2017 by Journal of Lake Sciences

\title{
坦噶尼喀湖东北部入湖河流表层沉积物中磷的形态和分布特征”
}

\author{
余 成 ${ }^{1,2}$, 陈 爽 ${ }^{1 * *}$, 张 路 ${ }^{1}$, 王兆德 ${ }^{1}$, 申秋实 ${ }^{1}$, 高 群 $^{1}$ \\ (1: 中国科学院南京地理与湖泊研究所流域地理学重点实验室,南京 210008) \\ (2: 中国科学院大学, 北京 100049)
}

\begin{abstract}
摘 要: 磷是坦噶尼喀湖生态系统中必不可少的营养元素, 直接决定湖体初级生产力的高低,进而影响到周边居民对于 动物蛋白的获取来源. 为了解坦噶尼喀湖磷的外源输人, 选择湖泊东北部的人湖河流, 对表层沉积物 (16 个样点) 中总磷 (TP) 和各形态磷含量及其分布特征进行分析, 并探讨磷的形态分布特征与土地利用方式之间的相关关系. 结果表明, 人 湖河流沉积物 TP 含量为 $73.05 ~ 239.94 \mathrm{mg} / \mathrm{kg}$, 平均含量为 $152.64 \pm 55.37 \mathrm{mg} / \mathrm{kg}$, 其中最高值出现在马拉加拉西河口. 采 用 Psenner 法对磷进行连续浸提并比较不同形态磷含量, 由高及低依次为铁铝结合态磷 $(\mathrm{Fe} / \mathrm{Al}-\mathrm{P})>$ 钲结合态磷 $(\mathrm{Ca}-\mathrm{P})>$ 有机磷 $($ Org-P) $)$ 残渣态磷 ( Res-P) > 弱吸附态磷 ( Labile-P). 土地利用类型对 TP 及各形态磷含量影响较大, 其中 TP 含量 表现为河口湿地 >城镇附近>林草地区, 表明地表径流和人类活动会对 TP 含量产生影响, 而对于不同形态磷含量, Laible-P、 $\mathrm{Fe} / \mathrm{Al}-\mathrm{P} 、 \mathrm{Org}-\mathrm{P}$ 含量均表现为河口湿地 $>$ 林草地 $>$ 城镇附近, Ca-P、Res-P 含量均表现为城镇附近 $>$ 河口湿地 $>$ 林草 地. 分析沉积物理化性质与各磷形态之间的相关性, 发现沉积物总氮 (TN)、有机质和总有机碳与 Fe/Al-P、Labile-P 和 TP 相关性较好, 与 Org-P、Ca-P 和 Res-P 相关性较差, 表明 TN 和有机质的输人,会伴随沉积物中磷含量的升高, 其增量的赋 存形态主要为氧化还原敏感态磷和 Labile-P. 沉积物粒径组成与各磷形态含量存在相关性, 细粒径沉积物与各形态磷含 量呈显著正相关,粗粒径沉积物与各形态磷呈显著负相关,表明细小颗粒更易吸附磷.
\end{abstract}

关键词: 坦噶尼喀湖; 人湖河流;沉积物;磷形态;土地利用

\section{Phosphorus fractions and their spatial distribution in surface sediments of inflow rivers in the northeastern Lake Tanganyika}

\author{
YU Cheng ${ }^{1,2}$, CHEN Shuang ${ }^{1 * *}$, ZHANG Lu ${ }^{1}$, WANG Zhaode ${ }^{1}$, SHEN Qiushi ${ }^{1} \&$ GAO Qun ${ }^{1}$ \\ (1: Key Laboratory of Watershed Geographic Sciences, Nanjing Institute of Geography and Limnology, Chinese Academy of \\ Sciences, Nanjing 210008, P.R.China) \\ (2: University of Chinese Academy of Sciences, Beijing 100049, P.R.China)
}

Abstract: Phosphorus is an essential nutrient in the Lake Tanganyika ecosystem, which determines the lake's primary productivity, and subsequently influences the animal protein sources for riparian residents. To understand the external inputs of phosphorus to the Lake Tanganyika, 16 surface sediment samples from the rivers which flow into the northeastern lake were collected and analyzed to understand the content and spatial distribution of the total phosphorus ( TP), and the relationship between land use pattern and the spatial distribution of different phosphorus forms. The TP content in surface sediment varied from 73.05 to $239.94 \mathrm{mg} / \mathrm{kg}$, with an average content of $152.64 \pm 55.37 \mathrm{mg} / \mathrm{kg}$, and the highest content was observed at Malagarasi river mouth. Using the sequential extraction method(Psenner) the phosphorus fractionation distribution of sediments was analyzed. The results showed that sequences of the contents of different phosphorus forms was Fe/Al-P > Ca-P > Org-P > Res-P > Labile-P. The TP content was highest in the estuarine wetlands, followed by that in urban areas, and the lowest content was in the woodland. It implies that land use had significant impacts on the content of TP and phosphorus forms. The patterns also implied that surface runoff and human activities would be the causes of the TP accumulation in the surface sediment of inflowing rivers. The spatial distribution of different phosphorus forms differed from that of TP. The highest content of Liable-P, Fe/Al-P and Org-P were observed in the estuarine wetland, and

* 中国科学院海外科教基地建设计划项目 (SAJC201319) 资助.2016-03-21 收稿;2016-05-12 收修改稿.余成 (1987 ),女,博士研究生;E-mail :yucheng823@126.com.

** 通信作者;E-mail: schens@ niglas.ac.cn. 
then followed by those in the woodland.The urban area had the lowest contents. The highest contents of Ca-P and Res-P were found in urban area, and then followed by estuarine wetland. The woodland had the lowest content. According to the correlation analyses between the contents of different $\mathrm{P}$ forms and particle size of sediments, total nitrogen ( TN), loss of ignition ( LOI), and total organic carbon (TOC), it was found that TN, LOI and TOC had significantly positive correlations with the Fe/ Al-P, Labile-P and TP contents, while they had weak correlations with Org-P, Ca-P and Res-P. It indicated that the input of TN and organic matter would increase the content of phosphorus in the sediment, and the incremental P forms were Fe/ Al-P and Liable-P. There were significant and positive correlations between fine particle sediments and the contents of different phosphorus forms, while significant and negative correlations existed between coarse sand and the contents of phosphorus forms. These results indicate that fine particle sediments are easier to adsorb the phosphorus.

Keywords: Lake Tanganyika; inflowing rivers; sediments; phosphorus fraction; land use

磷是湖泊生态系统中必不可少的营养元素, 过剩的磷会导致湖泊的富营养化, 从而使湖泊生态平衡遭 到破坏 ${ }^{[1]}$, 磷在湖泊生态系统中的循环是人们极为关注的问题. 通过各种途径进人水体的磷, 在矿物表面吸 附或与铝、铁和钻等元素共沉淀作用 ${ }^{[2-3]}$ 最终进人水体沉积物,通过再悬浮、化学扩散和微生物分解等过程, 沉积物中的磷可释放到上覆水体 ${ }^{[4-5]}$. 因此, 沉积物是地表水环境中磷重要的源和汇, 分析沉积物中磷的不 同化学形态及其含量, 有助于研究水体中磷的形态、动态循环以及磷在水-沉积物界面的迁移转化过程 ${ }^{[6]}$.

坦噶尼喀湖 ( Lake Tanganyika) 位于赤道以南 ( $3 \sim 9^{\circ} \mathrm{S}, 29 \sim 31^{\circ} \mathrm{E}$ ), 是非洲第二大湖泊 (湖面面积约 32900 $\mathrm{km}^{2}$ ), 世界第二深湖 (最深处约 $\left.1470 \mathrm{~m}\right)^{[7]}$. 湖泊永久分层并有厌氧的深水层 ${ }^{[8]}$, 旱季 (5-9 月), 强烈的南 风使深水层营养盐上涌, 给上层水体带来丰富的氮、磷、硅等营养物质, 对于维持表层水体食物链具有重要 意义. 然而, 雨季 $(10-4$ 月), 大气沉降和河流输人的营养盐成为上层湖水营养盐的主要来源. 从二十世纪 初期开始, 随着全球气候变化和人类活动, 湖泊初级生产力下降了 $20 \%$, 渔业产量下降了 $30 \%{ }^{[9]}$. 近年来湖 泊生态系统受流域人类活动影响程度逐渐升高.

Järvinen 等 ${ }^{[10]}$ 通过营养补充实验发现坦噶尼喀湖北部, 磷为主要限制性元素, 大量的磷元素人湖会导致 湖泊初级生产力的快速增加. 然而, 目前对坦噶尼喀湖外源营养盐输人的认识非常有限, 只针对几条较大的 人湖河流 (Rusizi 河、Malagarasi 河和 Lufubu 河) 开展了研究 ${ }^{[11-12]}$.

1994-1995 年间, Vandelannoote 等 ${ }^{[13]}$ 对 Rusizi 河进行了 10 次采样,并分析了 Rusizi 河对湖泊水质的影 响,与此同时, Langenberg 等 ${ }^{[12]}$ 对 Rusizi 河、Malagarasi 河和 Lufubu 河取样,评估了大气湿沉降和河流输人对 坦噶尼喀湖养分收支的重要性,并分析了外源营养盐对维持年初级生产力的作用. Brion 等 ${ }^{[11]}$ 在 1998 年 8 月至 1999 年 11 月间采集了坦噶尼喀湖北部 4 个点位的水样, 并分析了外源输入溶解性无机氮维持浮游植 物氮吸收的重要性,所有的这些研究均在 2000 年左右进行.

本文选择坦噶尼喀湖东北部的人湖河流, 对河流表层沉积物中各种形态磷的含量及其分布特征进行分 析, 研究磷的形态分布特征及其与土地利用类型之间的相关关系, 以期阐明坦噶尼喀湖外源输人性磷的潜 在释放风险, 为湖泊流域土地利用活动提供指导, 对于保护湖泊水生生物和生态系统,保障沿湖居民生活安 全有一定的现实意义.

\section{1 材料与方法}

\section{1 研究区概况}

本研究选择坦噶尼喀湖流域东北部人湖河流沉积物为研究对象, 研究区域分属布隆迪共和国布琼布拉 市辖区和坦桑尼亚联合共和国基戈马市辖区.

布琼布拉位于布隆迪共和国西部, 毗邻坦噶尼喀湖, 面积 $146 \mathrm{~km}^{2}$, 是沿湖流域最大的城市, 人口密度达 3276 人 $/ \mathrm{km}^{2[14]}$, 土壤类型主要为黏土和砂壤土, 布琼布拉属于热带干湿季气候, 旱季与雨季区别明显, 雨季 一般为 10-4 月, 旱季为 5-9 月, 气温范围为 $19 \sim 29^{\circ} \mathrm{C}$, 平均气温 $24^{\circ} \mathrm{C}$, 年均降水量为 $855 \mathrm{~mm}$. 布隆迪主要 的工业项目如啤酒业、日用化工业、造纸业和奶制品加工业等均位于布琼布拉.

基戈马是位于坦桑尼亚共和国西部的内陆城市, 基戈马地区 1978-1988 年之间人口增加了 31\%;2002 年, 基戈马地区人口密度则从 1978 年的 17.1 人 $/ \mathrm{km}^{2}$ 增加到 2002 年的 44 人 $/ \mathrm{km}^{2}$, 尤其是基戈马市区, 人口 
密度从 1978 年的 459.3 人 $\mathrm{km}^{2}$ 增加到 2002 年的 1127 人 $/ \mathrm{km}^{2}$. 基戈马地区年降水量范围为 $600 \sim 1600 \mathrm{~mm}$, 平均降水量为 $1100 \mathrm{~mm}$. 降水分布在 10-4 月,5-9 月降水量较少, 平均值不到 $50 \mathrm{~mm}$. 该市工业水平落后, 经济活动以农业为主, 近年来随着人口的自然增长和外来难民的涌人, 基戈马人口呈现快速增长的态势.

研究区位置和土地利用类型如图 1 所示 (土地利用分类数据来源于全球 $30 \mathrm{~m}$ 分辨率土地利用产品 Globe Land 30 (http://www.globallandcover.com/). 坦噶尼喀湖东北部土地利用类型分为耕地、森林、草地、灌 木、水体和人工表面六类. 其中人工表面主要包括城镇、乡村居民点及其周围基础设施、道路等. 受社会经济 发展水平的限制, 沿湖人工表面所占比例较低, 不超过 5\%. 耕地主要集中在城镇周边、乡村居民点和河流附 近, 受地形、水源和技术条件等限制, 坦噶尼喀湖沿湖耕地分布不连续, 耕地面积占土地面积的比例不超过 $30 \%$. 林地为本研究区的主要用地类型, 除少量原生林, 大部分为人工次生林、薪炭林和棕㭣林. 草地零散分 布在湖滨区域, 包括天然草地和部分耕地休耕后形成的草地. 坦噶尼喀湖沿湖土地利用强度较低, 农业和畜 牧业为主要利用方式. 布琼布拉市沿湖几千米范围内的各种工业和人类生产生活,包括: 纺织印染、酿酒、涂 料、肥㿝、蓄电池、燃料运输、港口和屠宰场等, 坦桑尼亚基戈马港运输活动和其发电设施以及沿湖耕地和棕 㭣林地施加的肥料等是坦噶尼喀湖沿湖氮、磷的主要来源.

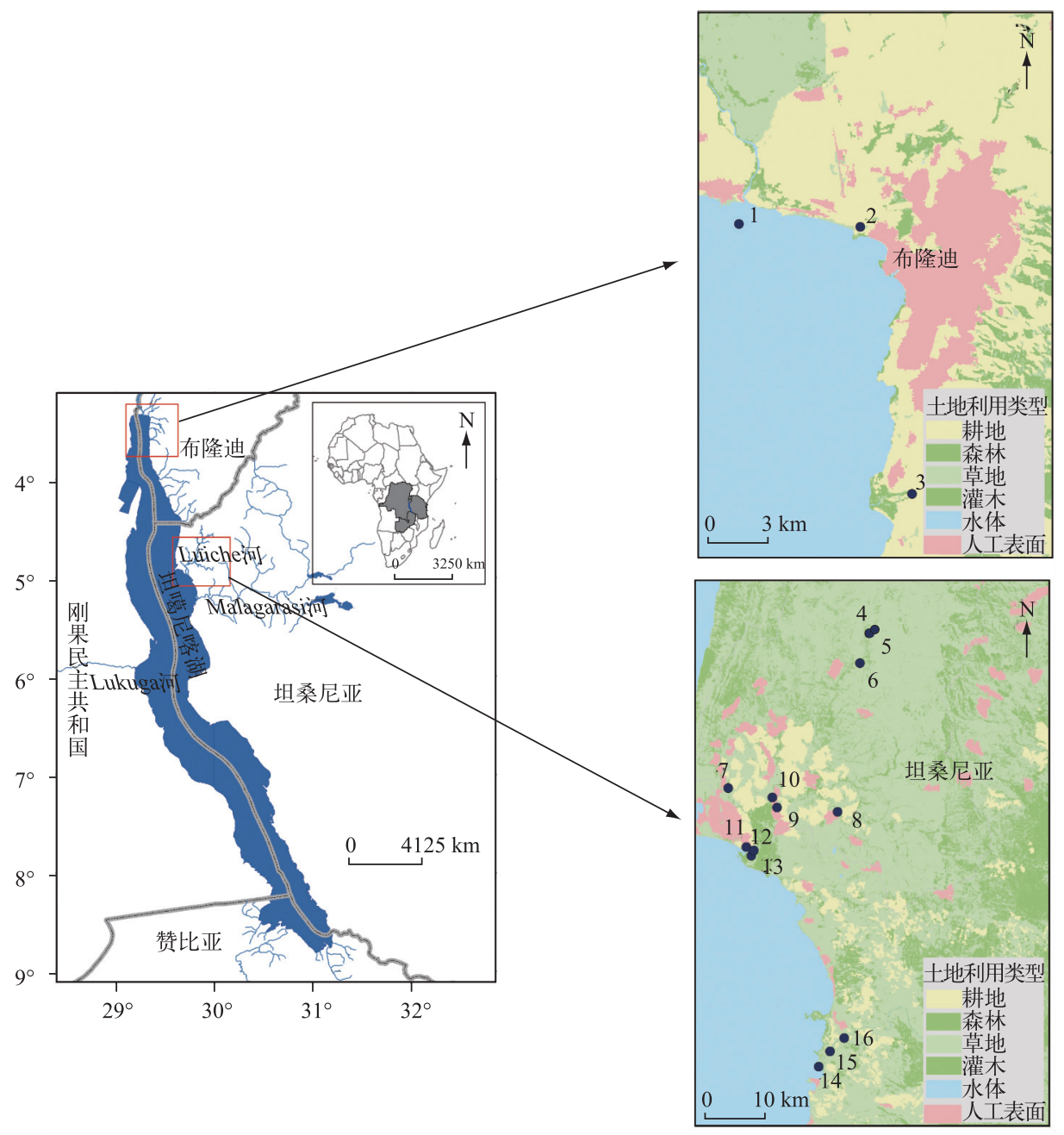

图 1 研究区位置及采样点分布示意

Fig. 1 The location of the study area and sampling sites 


\section{2 样品采集及分析}

2014 年 3 月在坦噶尼喀湖东北部布琼布拉市选择 3 条主要人湖河流, 在坦桑尼亚基戈马选择 Luiche 干 流、支流和河口以及马拉加西加 (Malagarasi) 河口共 16 个采样点 (图 1), 选择的人湖河流位于坦噶尼喀湖东 北部人口密集区, 该人湖河流具有较强的代表性,能够反映不同人类活动强度区域 (城市区域, 工农业活动 水平较低的 Luiche 流域) 的沉积物中磷的分布情况. 样点除了选择不同人湖河流中的常规点位, 还选择了特 殊点位如主要流域的汇水点,且基本涵盖了不同土地利用类型. 采样点河流名称及位置信息见文献 [15].

采用彼得森采泥器采集表层沉积物 $(0 \sim 10 \mathrm{~cm})$ 样品, 各个采样点的沉积物样品装人聚乙烯自封袋中密 封置于低温保温箱内保存,于 $24 \mathrm{~h}$ 内带回当地实验室,在坦桑尼亚渔业研究所基戈马中心实验室将沉积物 样品风干, 并带回国内. 在中国科学院南京地理与湖泊研究所湖泊与环境国家重点实验室按照孙千里等 ${ }^{[16]}$ 的方法对样品进行前处理, 将处理好的样品放人 Malven Mastersizer 2000 激光粒度分析仪 (英国), 其粒径测 量范围为 $0.02 \sim 2000 \mu \mathrm{m}$, 重复测量误差小于 $1 \%$, 为保证粒度分析的准确性和可靠性, 在测量过程中, 对仪 器的参数设置始终保持不变, 并对部分样品进行了重复测量. 将其他风干后的沉积物研磨, 过 100 目篮, 它 存在样品袋并封口备用, 用于分析沉积物总磷 (TP) 、总氮 (TN)、磷形态、总有机碳 (TOC) 含量和有机质 含量.

采用 Psenner 的磷连续提取法 ${ }^{[17-18]}$, 将磷形态分为弱吸附态磷 (Labile-P)、铁结合态磷 ( Fe-P) 、铝结合态 磷 ( Al-P)、有机磷 ( Org-P)、钙磷 ( Ca-P) 和残渣态磷 (Res-P), TP 为各形态磷的总和. 结果中将 Fe-P 和 Al-P 放在一起进行分析. TOC 含量采用 EA3000 元素分析仪测定 ${ }^{[19]}$, TN 含量采用碱性过硫酸钾消解法测定, 有 机质含量以沉积物干样在 $550^{\circ} \mathrm{C}$ 下灼烧 $6 \mathrm{~h}$ 的烧失量 $(\mathrm{LOI})$ 表示 ${ }^{[20]}$.

\section{2 结果与讨论}

\section{1 入湖河流表层沉积物理化性质}

坦噶尼喀湖人湖河流表层沉积物 TP 含量为 $73.05 \sim 239.94 \mathrm{mg} / \mathrm{kg}$, 平均含量为 $152.64 \mathrm{mg} / \mathrm{kg}$, 其中马拉 加西加河口 TP 含量最高. 沉积物 TN 、LOI 和 TOC 含量最高值也位于马拉加西加河口, TN 含量为 194 4149 $\mathrm{mg} / \mathrm{kg}$, 平均含量为 $939.43 \mathrm{mg} / \mathrm{kg}$; LOI 含量为 $0.52 \% \sim 18.13 \%$, 平均含量为 $4.03 \%$; TOC 含量在 $0.047 \% \sim$ $4.511 \%$ 之间, 除马拉加西加河口外, 其他点位 TOC 含量均较低 (表 1).

根据国际上应用较广的伍登-温特华斯的粒度分级方案 (砂 $(0.063 \sim 2 \mathrm{~mm}$ )、粉砂 $(0.0039 \sim 0.063 \mathrm{~mm}$ ) 和黏土 $\left.(<0.0039 \mathrm{~mm})^{[21]}\right)$ 对入湖河流表层沉积物进行粒度分析, 坦噶尼喀湖东北部人湖河流粒径划分结果 如表 1 所示. 所有人湖河流表层沉积物大部分为砂 (质量分数为 $44.98 \% \sim 94.33 \%$ ), 粉砂和黏土质量分数较 低, 分别为 $3.37 \% \sim 36.29 \%$ 和 $0.55 \% \sim 19.8 \%)$. 砂含量的最高值出现在 $9^{\#}$ 点, 最低值出现在 Malagarasi 河口 ( $16^{\#}$ 点), 所有人湖河流砂含量的平均值为 $76.10 \%$. 粉砂含量的最低值则出现在 $6^{\#}$ 点 (3.37\%), 最高值出现 在 Luiche 河口 ( $13^{\text {点 }}, 36.29 \%$ ), 所有人湖河流粉砂含量的平均值为 $18.37 \%$. 所有人湖河流中黏土含量最

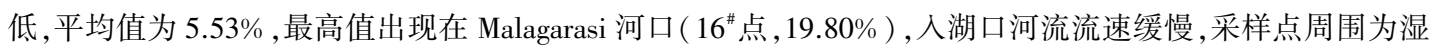
地, 水生植物较多, 且沿岸分布大量草地, 对粗颗粒物有拦截作用, 表层沉积物中含有植物腐殖质, 这些是河 口地区黏土含量相对较高的原因.

\section{2 入湖河流表层沉积物各形态磷含量特征}

人湖河流表层沉积物弱吸附磷 (Labile-P) 含量在 $0.12 \sim 0.85 \mathrm{mg} / \mathrm{kg}$ 之间, 平均值为 $0.42 \mathrm{mg} / \mathrm{kg}$, 占 TP 比 例最低, 不足 $1 \%$; 铁铝结合磷 $(\mathrm{Fe} / \mathrm{Al}-\mathrm{P})$ 是 $\mathrm{TP}$ 的主要形式, 占 $\mathrm{TP}$ 的 $63 \%$, 含量在 $42.63 \sim 184.54 \mathrm{mg} / \mathrm{kg}$ 之 间, 平均含量为 $96.16 \mathrm{mg} / \mathrm{kg}$; 䥻结合磷 (Ca-P) 平均含量为 $25.3 \mathrm{mg} / \mathrm{kg}$, 占 $\mathrm{TP}$ 的 $16.6 \%$, 有机磷 ( Org-P) 平均 含量为 $15.51 \mathrm{mg} / \mathrm{kg}$, 占 TP 的 $10.2 \%$; 残渣态磷 (Res-P) 平均含量为 $15.26 \mathrm{mg} / \mathrm{kg}$, 占 TP 的 $9.99 \%$ (表 2, 图 2). 表层沉积物中不同形态磷含量大小表现为 Fe/Al-P> Ca-P> Org-P $>$ Res-P > Labile-P. 该研究区 Fe/Al-P 占 TP 含量最高, 这与该地区沉积物和流域土壤性质有关, 沉积物中 Fe/Al-P 含量通常与 TP 含量呈正比, 沿 湖地区土壤以铁铝土为主要类型, 铁、铝、锰、钛氧化物含量较高, 并常有游离的铁、铝存在, 磷易于被铁、铝 等金属元素固定, 坦噶尼喀湖人湖河流上覆水和沉积物均呈碱性 ${ }^{[15]}$, 磷一旦被固定, 在碱性环境中不易释 放, 因此 $\mathrm{Fe} / \mathrm{Al}-\mathrm{P}$ 含量较高. 
表 1 人湖河流表层沉积物理化性质*

Tab.1 General chemical characteristics of the surface sediment of the inflow rivers

\begin{tabular}{|c|c|c|c|c|c|c|c|c|c|c|}
\hline \multirow[b]{2}{*}{ 样点 } & \multicolumn{6}{|c|}{ 人湖河流表层沉积物 } & \multicolumn{3}{|c|}{ 不同粒径的沉积物质量分数/\% } & \multirow{2}{*}{$\begin{array}{l}\text { 中值粒 } \\
\text { 径/mm }\end{array}$} \\
\hline & $\begin{array}{l}\text { 样点水 } \\
\text { 深/m }\end{array}$ & $\begin{array}{l}\text { 河流宽 } \\
\text { 度/m }\end{array}$ & $\begin{array}{c}\mathrm{TN} / \\
(\mathrm{mg} / \mathrm{kg})\end{array}$ & $\begin{array}{l}\text { LOI/ } \\
\%\end{array}$ & $\begin{array}{c}\text { TOC/ } \\
\%\end{array}$ & $\begin{array}{c}\mathrm{TP} / \\
(\mathrm{mg} / \mathrm{kg})\end{array}$ & $\begin{array}{c}<0.0039 \\
\mathrm{~mm}\end{array}$ & $\begin{array}{l}0.0039 \sim \\
0.063 \mathrm{~mm}\end{array}$ & $\begin{array}{c}0.063 \sim \\
2 \mathrm{~mm}\end{array}$ & \\
\hline 1 & 2.0 & 30 & 372.11 & 2.10 & 0.103 & 183.75 & 3.58 & 35.22 & 61.20 & 0.083 \\
\hline 2 & 1.0 & 2.0 & $194.36^{\nabla}$ & 0.95 & $0.047^{\nabla}$ & 208.95 & $0.55^{\nabla}$ & 13.48 & 85.97 & 0.132 \\
\hline 3 & 1.0 & 5.0 & 388.57 & 1.87 & 0.134 & 195.60 & 2.62 & 28.51 & 68.87 & 0.111 \\
\hline 4 & 1.5 & 3.0 & 490.70 & 1.87 & 0.114 & 76.80 & 4.94 & 6.24 & 88.82 & 0.463 \\
\hline 5 & 0.7 & 5.0 & 1252.66 & 8.69 & 0.056 & 132.00 & 5.53 & 4.96 & 89.51 & 0.453 \\
\hline 6 & 1.0 & 5.0 & 996.56 & 3.44 & 0.158 & 134.40 & 4.26 & $3.37^{\nabla}$ & 92.38 & $0.495^{\triangle}$ \\
\hline 7 & 0.8 & 2.0 & 249.31 & $0.52^{\nabla}$ & 0.273 & $73.05^{\nabla}$ & 2.88 & 17.27 & 79.85 & 0.108 \\
\hline 8 & 1.0 & 2.5 & 568.92 & 1.42 & 0.184 & 93.00 & 2.62 & 11.87 & 85.51 & 0.438 \\
\hline 9 & 1.5 & 5.0 & 547.18 & 2.50 & 0.114 & 118.05 & 0.69 & 4.98 & $94.33^{\triangle}$ & 0.465 \\
\hline 10 & 1.0 & 3.5 & 207.09 & 0.80 & 0.061 & 111.75 & 0.79 & 8.11 & 91.10 & 0.458 \\
\hline 11 & 1.0 & 20.0 & 788.75 & 2.58 & 0.170 & 124.65 & - & - & - & - \\
\hline 12 & 2.0 & 20.0 & 961.05 & 2.18 & 0.205 & 118.35 & 2.53 & 18.11 & 79.36 & 0.341 \\
\hline 13 & 4.0 & 20.0 & 625.93 & 3.50 & 0.223 & 199.80 & 11.10 & $36.29^{\triangle}$ & 52.61 & 0.068 \\
\hline 14 & 5.0 & 80.0 & 451.39 & 1.63 & 0.142 & 194.97 & 8.55 & 17.35 & 74.10 & 0.089 \\
\hline 15 & 6.0 & 80.0 & 2787.57 & 12.24 & 2.465 & 237.15 & 12.50 & 34.55 & 52.95 & 0.075 \\
\hline 16 & 7.5 & 80.0 & $4148.73^{\triangle}$ & $18.13^{\triangle}$ & $4.511^{\triangle}$ & $239.94^{\triangle}$ & $19.80^{\triangle}$ & 35.22 & $44.98^{\nabla}$ & $0.055^{\nabla}$ \\
\hline 平均值 & & & $939.43 \pm 1060.2$ & $4.03 \pm 4.86$ & $0.560 \pm 1.20$ & $152.64 \pm 55.37$ & $5.53 \pm 5.36$ & $18.37 \pm 12.42$ & $76.10 \pm 16.28$ & $0.26 \pm 0.19$ \\
\hline
\end{tabular}

$* \nabla$ 表示含量最低值, $\triangle$ 表示含量最高值, “一”表示未测出.

表 2 人湖河流表层沉积物中各形态磷含量

Tab.2 Contents of each phosphorus fractionation in sediment samples of inflow rivers

\begin{tabular}{lcccccc}
\hline 统计量 & $\begin{array}{c}\mathrm{TP} / \\
(\mathrm{mg} / \mathrm{kg})\end{array}$ & $\begin{array}{c}\text { Labile-P/ } \\
(\mathrm{mg} / \mathrm{kg})\end{array}$ & $\begin{array}{c}\mathrm{Fe} / \mathrm{Al}-\mathrm{P} / \\
(\mathrm{mg} / \mathrm{kg})\end{array}$ & $\begin{array}{c}\text { Org-P/ } \\
(\mathrm{mg} / \mathrm{kg})\end{array}$ & $\begin{array}{c}\mathrm{Ca}-\mathrm{P} / \\
(\mathrm{mg} / \mathrm{kg})\end{array}$ & $\begin{array}{c}\text { Res-P/ } \\
(\mathrm{mg} / \mathrm{kg})\end{array}$ \\
\hline 最小值 & 73.05 & 0.12 & 42.63 & 3.53 & 3.86 & 1.83 \\
最大值 & 239.94 & 0.85 & 184.54 & 35.9 & 87.13 & 50.48 \\
平均值 & 152.64 & 0.42 & 96.16 & 15.51 & 25.30 & 15.26 \\
标准差 & 55.37 & 0.20 & 42.83 & 9.23 & 27.09 & 11.64 \\
变异系数 $/ \%$ & 36.28 & 48.38 & 44.56 & 59.53 & 107.11 & 76.28 \\
\hline
\end{tabular}

\section{3 入湖河流表层沉积物 TP 及各形态磷含量空间分布特征}

人湖河流表层沉积物中各形态磷含量和空间分布特征能够表征河流环境的污染程度和地球化学信息, 反映沉积物中磷可被生物利用的潜在能力. 坦噶尼喀湖人湖河流沉积物中 TP 和各形态磷的空间分布特征 可以看出, 人湖河流表层沉积物中 TP 含量最高值出现在 Malagarasi 河口(图 3), Malagarasi 河是坦噶尼喀湖 最大的人湖河流, 流域面积占坦噶尼喀湖流域面积的 $1 / 3$, 平均流量为 $165 \mathrm{~m}^{3} / \mathrm{s}^{[11]}$, 河岸分布大片的棕榈林 和农田, 经过实地调查发现棕榈树作为当地的经济树种, 为提高产量, 农户会施加肥料和杀菌剂等. 采样时 间处于当地雨季, 流域物质通过地表径流进人河流最终汇集于河口, 人湖口河流流速缓慢, 大量物质在人湖 口沉积, 导致河口地区沉积物中 TP 含量较高. 其他高值点则出现在 $2^{\#}$ 和 $3^{\#}$ 点, 这 2 个点均位于布琼布拉市, 采样点周围分别分布啤酒厂和屠宰场, 且采样点上游分布大片耕地. 由于污水处理设施不完善, 工业污水和 生活污水直接排人河流, 导致河流氮磷含量增加, 布琼布拉从 1990-2008 年人口增加了 $103 \%$, 达到约 50 万 $^{[14]}$,人口密度达到 3276 人 $/ \mathrm{km}^{2}$, 快速增长的人口集聚在沿湖区域,将会导致水体的恶化.

沉积物中 Labile-P 和 Fe/Al-P 是最容易进人上覆水体从而影响水体磷酸盐含量的磷形态. 坦噶尼喀湖 


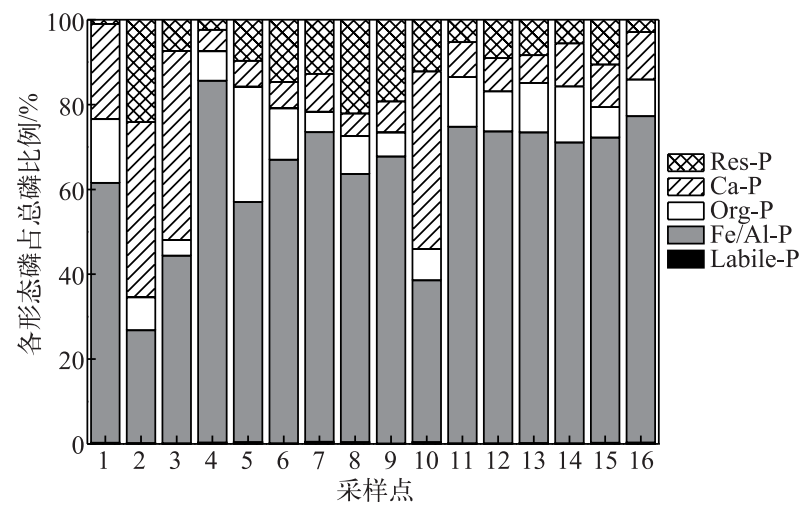

图 2 人湖河流表层沉积物各形态磷分布特征

Fig.2 Distribution characteristics of each phosphorus fractionation in surface sediment of inflow rivers

人湖河流各点位中 Labile-P 的含量较低, 均小于 $1 \mathrm{mg} / \mathrm{kg}$. Fe/Al-P 的空间分布特征与 TP 一致, 含量最高值 出现在马拉加西加河口, 表明马拉加西加流域大量的还原性物质通过地表径流进人河流, $\mathrm{Fe} / \mathrm{Al}-\mathrm{P}$ 容易受到 氧化还原电位影响, 释放到水体中, 属于风险性磷形态.

Ca-P 和 Org-P 是沉积物中较为稳定态的磷, 人湖河流偏碱性的环境中, 这部分磷比较稳定. 人湖河流沉 积物中 Ca-P 含量最高值位于 $3^{\#}$ 点, 其次为 $2^{\#}$ 点, 均处于布琼布拉市. Org-P 含量的空间分布特征与 TP 含量 不同, 最高值位于 $5^{\#}$ 点, 含量为 $35.9 \mathrm{mg} / \mathrm{kg}, \mathrm{Org}-\mathrm{P}$ 部分可为生物所利用, 主要来源于农业面源, 经过实地调 查发现 $5^{\#}$ 点周围主要为农田休耕地生长的次生草地和棕榈林地,受农业活动影响较大.
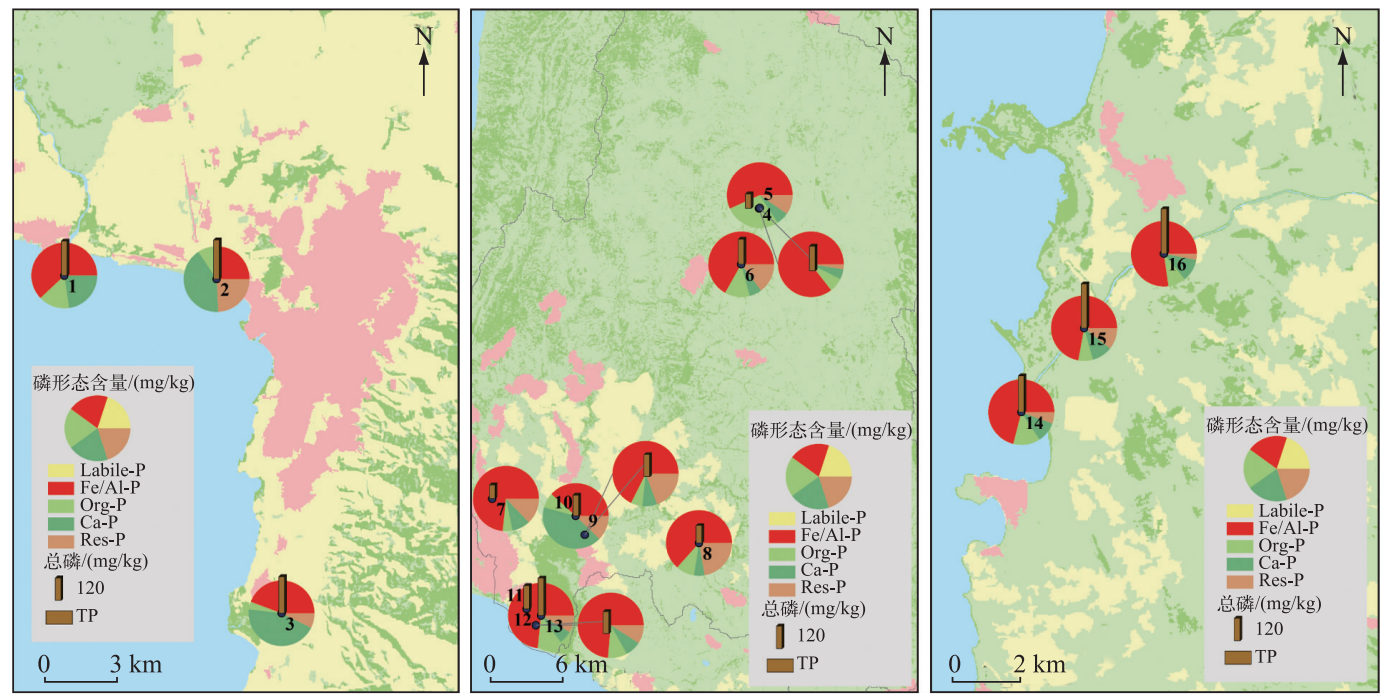

图 3 人湖河流表层沉积物总磷及各形态磷含量空间分布

Fig.3 The spatial distribution of total phosphorus and phosphorus fractionation in surface sediments of inflow rivers

\section{4 不同土地利用类型对磷含量及各形态的影响}

根据文献 $[15]$, 本研究区土地利用类型可分为三类功能区,包括城镇区、河口湿地和林草地区, 其中 $2^{\#} \sim$ $3^{\# 、} 7^{\#} \sim 10^{\#}$ 点位于城镇地区; $1^{\#} 、 11^{\#} \sim 16^{\#}$ 位于河口湿地; $4^{\#} \sim 6^{\#}$ 位于林草地区. 三类功能区中河口湿地 TP 含量 最高, 平均含量为 $185.52 \mathrm{mg} / \mathrm{kg}$, 其次为城镇附近, TP 平均含量为 $133.40 \mathrm{mg} / \mathrm{kg}$, 林草地区 $\mathrm{TP}$ 含量最低, 平 


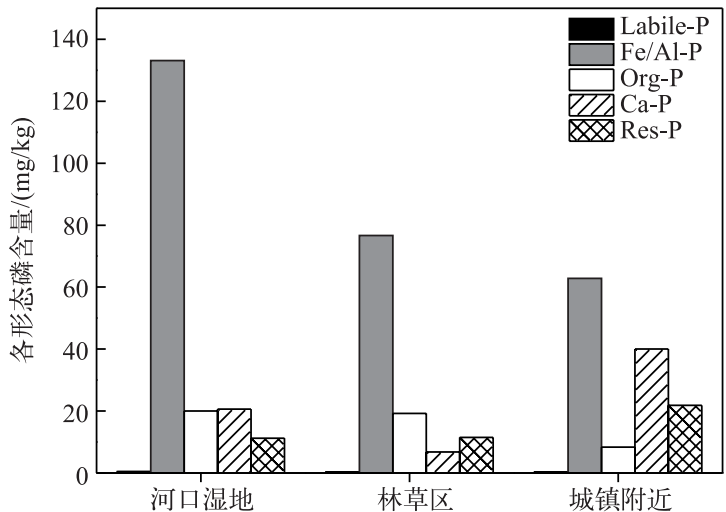

图 4 三类功能区表层沉积物各形态磷含量分布

Fig.4 The distribution of each phosphorus fractionation content in three different functional zones
均含量为 $114.40 \mathrm{mg} / \mathrm{kg}$. Rusizi 河和 Malagarasi 河是坦噶尼喀湖最主要的人湖河流, 其中 Rusizi 河年流量为 $182.4 \mathrm{~m}^{3} / \mathrm{s}$, Malagarasi 河的年流量 为 $165 \mathrm{~m}^{3} / \mathrm{s}^{[11]}$, 流域氮磷等营养盐通过地表径 流进人河流, 最终汇集于河口, 河口表层沉积物 黏土含量最高, 范围为 $2.53 \% \sim 19.80 \%$, 平均含 量为 $9.68 \%$, 细小颗粒物更易吸附磷 ${ }^{[22]}$, 使河口 湿地表现为 TP 含量最高. 城镇附近由于受到人 类生活污水和工业废水排放影响, 河流沉积物 $\mathrm{TP}$ 含量也较高.

Labile-P 在三类土地功能区含量均较低, 不 超过 $1 \mathrm{mg} / \mathrm{kg}$. Fe/Al-P 含量最高值出现在河口 湿地, 平均含量为 $133.141 \mathrm{mg} / \mathrm{kg}$, 其次为林草地 区, 平均含量为 $76.629 \mathrm{mg} / \mathrm{kg}$, 城镇附近含量最 低, 平均为 $62.777 \mathrm{mg} / \mathrm{kg}, \mathrm{Fe} / \mathrm{Al}-\mathrm{P}$ 在三类功能区

占 TP 比例均最高. Org-P 在三类功能区的分布特点与 $\mathrm{Fe} / \mathrm{Al}-\mathrm{P}$ 一致, 最高含量位于河口湿地, 其次为林草 地, 城镇地区含量最低, 河口湿地风险性磷含量最高, 可能对湖泊的初级生产力产生影响; 城镇地区 Ca-P 和 Res-P 含量最高, 分别为 40.049 和 $21.851 \mathrm{mg} / \mathrm{kg}$ (图 4).

\section{5 沉积物理化性质对磷形态的影响分析}

通过分析沉积物中 TP 和磷形态与理化性质(如有机质含量、粒径组成等)之间的关系可以用来推断沉 积物中磷的特性. 如史静等 ${ }^{[23]}$ 发现滇池沉积物中有机质对磷的释放和吸附具有很大影响. 本研究分析了沉 积物样品中各形态磷含量与 TN、LOI、TOC 和粒径的相关性, 结果见表 3.

沉积物样品中 TN 、LOI 和 TOC 与 Fe/Al-P、Labile-P 含量有显著的相关性, 与 TP 相关性较好, 与 Org-P、 Ca-P 和 Res-P 含量相关性较差, 表明 TN 和有机质的输人, 会导致沉积物中磷含量的升高, 其增量的赋存形 态主要为氧化还原敏感态磷和弱结合态磷. 粒径组成与各形态磷含量存在相关性, 细粒径与各形态磷含量 呈显著正相关 $(P<0.01)$, 粗粒径与各形态磷含量呈显著负相关 $(P<0.01)$. 各粒径相关性关系中, Labile-P、 $\mathrm{Fe} / \mathrm{Al}-\mathrm{P}$ 和 TP 含量与黏土呈极显著正相关 $(P<0.01)$, Labile-P、Fe/Al-P 含量与粉砂呈显著相关 $(P<0.05)$, $\mathrm{TP}$ 含量则与黏土和粉砂均呈极显著正相关 $(P<0.01)$. Labile-P、 Fe/ Al-P 和 TP 与砂均存在极显著负相关 $(P<0.01)$, 这表明 Labile-P、Fe/Al-P 和 TP 分布与黏土及细粉砂等细颗粒沉积物密切相关 (表 3$)$, 此结果与 何会军等 ${ }^{[24]}$ 研究长江口表层沉积物中可交换态磷与黏土及细粉砂等细颗粒显著相关的结果一致, Org-P、 Ca-P、Res-P 含量与粒径没有明显的相关性.

表 3 人湖河流沉积物理化性质与各形态磷含量相关性

Tab.3 Correlation between each phosphorus fractionation content and physical-chemical characteristics of inflow rivers

\begin{tabular}{|c|c|c|c|c|c|c|c|}
\hline \multirow{2}{*}{ 磷形态 } & \multirow{2}{*}{$\mathrm{TP}$} & \multirow{2}{*}{$\mathrm{TN}$} & \multirow{2}{*}{ LOI } & \multirow{2}{*}{ TOC } & \multicolumn{3}{|c|}{ 粒径/mm } \\
\hline & & & & & $<0.0039$ & $0.0039 \sim 0.063$ & $0.063 \sim 2$ \\
\hline Labile-P & $0.575^{*}$ & $0.677^{*}$ & 0.761 * & $0.705^{* *}$ & $0.722^{* * *}$ & $0.518^{*}$ & $-0.635^{* * *}$ \\
\hline $\mathrm{Fe} / \mathrm{Al}-\mathrm{P}$ & $0.777^{\text {*** }}$ & $0.744^{*}$ & $0.730^{*}$ & $0.731^{\text {** }}$ & $0.893^{* *}$ & $0.745^{*}$ & $-0.864^{* *}$ \\
\hline Org-P & $0.514^{*}$ & 0.272 & 0.406 & 0.142 & 0.424 & -0.271 & -0.347 \\
\hline $\mathrm{Ca}-\mathrm{P}$ & $0.509^{*}$ & -0.147 & -0.111 & -0.018 & -0.175 & 0.266 & -0.144 \\
\hline Res-P & 0.296 & -0.097 & -0.084 & -0.080 & -0.206 & -0.161 & 0.191 \\
\hline $\mathrm{TP}$ & 1 & $0.532^{*}$ & $0.563^{*}$ & $0.567^{*}$ & $0.635^{* * *}$ & $0.719^{* *}$ & $-0.759^{* *}$ \\
\hline
\end{tabular}

$* P<0.05, * * P<0.01$. 


\section{3 结论}

坦噶尼喀湖人湖河流沉积物中不同形态磷含量大小表现为 Fe/Al-P $>$ Ca-P $>$ Org-P $>$ Res-P $>$ Labile-P, 人湖 河流以风险性磷为主, Fe/ Al-P 含量最高, 与流域土壤和沉积物性质有关. 沉积物中 TP 和各形态磷含量空间 差异较大, 在三类土地功能区, TP 含量表现为河口湿地>城镇附近>林草地区,各形态磷含量空间分布有所 差异, 其中 Laible-P、Fe/Al-P 和 Org-P 含量均表现为河口湿地 > 林草地 > 城镇附近; Ca-P 和 Res-P 含量均表现 为城镇附近 $>$ 河口湿地 $>$ 林草地.

表层沉积物磷形态含量与 TN、LOI 和粒径的相关性分析显示, TN 、LOI 和 TOC 与 Fe/Al-P、Labile-P 和 TP 含量相关性较好, 与 Org-P、Ca-P 和 Res-P 含量相关性较差; 表明 TN 和有机质的输人会增加沉积物中的 磷含量, 且增量主要来自氧化还原敏感态磷和弱结合态磷. 粒径组成与各形态磷含量存在相关性, Labile-P、 $\mathrm{Fe} / \mathrm{Al}-\mathrm{P}$ 和 TP 含量与黏土和细粉砂呈显著正相关, 与砂呈极显著负相关, 表明 Labile-P、Fe/Al-P 和 TP 的分 布与黏土及细粉砂等细颗粒沉积物密切相关, 细小颗粒更易吸附磷.

坦噶尼喀湖流域属于欠发达地区,农业活动强度低于尼罗河和维多利亚湖流域,湖水总体呈现营养盐 含量低、碱度和 $\mathrm{pH}$ 值高、重金属检出率低的特征 ${ }^{25]}$. 近年来沿湖国家人口增长速度较快, 年均增长率保持 在 3\% 以上, 快速增长的人口集聚在沿湖区域, 沿湖城镇污水处理设施有限, 大量无处理的生活污水和农业 活动产生的面源污染极易导致河流和湖泊水质恶化. 本文首次探讨了坦噶尼喀湖人湖河流表层沉积物 TP、 各形态磷含量及其与土地利用类型的关系, 发现城镇地区的生活和农业活动会对河流产生影响, 随着沿湖 社会经济的发展以及人口的快速增加, 这种影响会逐渐加剧, 并会对坦噶尼喀湖湖泊水质和生态系统产生 影响, 因此加强湖泊和人湖河流的长期监测, 对于科学维持和保护坦噶尼喀湖水环境质量和生态系统, 合理 规划和管理坦噶尼喀湖及其流域内工业、农业和渔业发展,具有重要的环境与生态意义.

致谢: 在非洲采样过程中, 坦噶尼喀湖管理委员会 (Lake Tanganyika Authority) 环境执行主任 Gabriel Hazikimana 先生, 坦桑尼亚渔业研究所基戈马中心主任 Kimirei Ismeal 博士给予了大力帮助, 孔明、唐陈态、姚晓 龙、王源、部倩玉在实验测定过程中给予了帮助, Damas Mapunda、王磊在论文修改过程中提出了宝贵的建议. 在此,向他们表示衷心的感谢.

\section{4 参考文献}

[ 1 ] Weng Huanxin, Liu Yunfeng, Dan Armstrong. On phosphorus in strand sediment and interstitial water. Acta Scientiae Circumstantiae Act , 1997, 17(2) : 148-153. DOI : 10.136 71/j.hjkxxb.1997.0.004.[翁焕新, 刘云峰, Dan Armstrong. 滨 海沉积物和间隙水中的磷研究——美国墨西哥湾为例. 环境科学学报, 1997, 17(2): 148-153.]

[ 2 ] House WA, Denison FH. Phosphorus dynamics in a lowland river. Water Research, 1998, 32(6) : 1819-1830. DOI: 10. 1016/S0043-1354(97) 00407-7.

[ 3 ] Fox I, Malati MA, Perry R. The absorption and release of phosphate from sediments of river receiving sewage effluent. Water Research, 1989, 23(6) : 725-732. DOI: 10.1016/0043-1354(89) 90206-6.

[ 4 ] Sun Xiaojing, Qin Boqiang, Zhu Guangwei et al. Release of colloidal N and P from sediment of lake caused by continuing hydrodynamic disturbance. Environmental Science, 2007, 28(6): 1223-1229. [孙小静, 秦伯强, 朱广伟等. 持续水动 力作用下湖泊底泥胶体态氮、磷的释放. 环境科学, 2007, 28(6) : 1223-1229.]

[ 5 ] Li Dapeng, Huang Yong, Li Weiguang. Formation mechanism of bioavailable phosphorus in sediments under the conditions of sediment re-suspension. Environmental Science, 2008, 29(7) : 1824-1830. DOI: 10.13227/j.hjkx.2008.07.015. [李大 鹏, 黄勇, 李伟光. 底泥再悬浮状态下生物有效磷形成机制研究.环境科学, 2008, 29(7) : 1824-1830.

[ 6 ] Hu Chuanyu, Pan Jianming, Liu Xiaoya. Species of phosphorus in sediments from Peal River Estuary. Marine Environmental Science, 2001, 20(4) : 21-25. [扈传昱, 潘建明, 刘小涯.珠江口沉积物中磷的赋存形态.海洋环境科学, 2001, $20(4): 21-25$.]

[ 7 ] Plisnier PD, Chitamwebwa D, Mwape L et al. Limnological annual cycle inferred from physical-chemical fluctuations at three stations of Lake Tanganyika. Netherlands: Springer, 1999: 45-58. DOI: 10.1007/978-94-017-1622-2_4.

[ 8 ] Beauchamp RSA. Hydrology of Lake Tanganyika. Internationale Revue der Gesamten Hydrobiologie und Hydrographie, 1939, 39(3/4) : 316-353. DOI: 10.1002/iroh.19390390303. 
[ 9 ] O'Reilly CM, Alin SR, Plisnier PD et al. Climate change decreases aquatic ecosystem productivity of Lake Tanganyika, Africa. Nature, 2003, 424(6950): 766-768. DOI: 10.1038/nature01833.

[10] Järvinen M, Salonen K, Sarvala J et al. The stoichiometry of particulate nutrients in Lake Tanganyika-Implications for nutrient limitation of phytoplankton. Netherlands: Springer, 1999: 81-88. DOI: 10.1007/978-94-017-1622-2_8.

[11] Brion N, Nzeyimana E, Goeyens L et al. Inorganic nitrogen uptake and river inputs in Northern Lake Tanganyika. Journal of Great Lakes Research, 2006, 32(3) : 553-564. DOI: http: //dx.doi.org/10.3394/0380-1330 (2006) 32 [ 553: INU$\mathrm{ARI}] 2.0 . \mathrm{CO} ; 2$.

[12] Langenberg VT, Nyamushahu S, Roijackers R et al. External nutrient sources for Lake Tanganyika. Journal of Great Lakes Research, 2003, 29: 169-180. DOI: 10.1016/S0380-1330(03)70546-2.

[13] Vandelannoote A, Deelstra H, Ollevier F. The inflow of the Rusizi river to Lake Tanganyika. Netherlands: Springer, 1999: 65-73. DOI: 10.1007/978-94-017-1622-2_6.

[14] Bigirimana J. Urban plant diversity patterns, processes and conservation value in Sub-Saharan Africa: Case of Bujumbura in Burundi. Bruxelles: Université Libre de Bruxelles, 2012: 45.

[15] Yu Cheng, Chen Shuang, Zhang Lu. Distribution and potential ecological risk assessment of heavy metals in surface sediments of inflow rivers to Northeastern Lake Tanganyika. Environmental Science, 2016, 37(2) : 97-104. DOI : 10.13227/j/ hjkx.2016.02.013. [ 余成, 陈爽, 张路. 坦噶尼喀湖东北部人湖河流沉积物重金属分布特征与生态风险评价. 环境 科学, 2016, 37(2): 97-104.]

[16] Sun Qianli, Zhou Jie, Xiao Jule. Grain-size characteristics of Lake Daihai sediments and its paleaoenvironment significance. Marine Geology \& Quaternary Geology, 2001, 21(1) : 93-95. [孙千里, 周杰, 肖举乐. 岱海沉积物粒度特征及 其古环境意义. 海洋地质与第四纪地质, 2001, 21(1) : 93-95.]

[17] Ruban V, Lopez-Sanchez JF, Pardo P et al. Selection and evaluation of sequential extraction procedures for the determination of phosphorus forms in lake sediment. Journal of Environmental Monitoring, 1999, 1 (1): 51-56. DOI: 10. 1039/A807778I.

[18] Emil R. Potentially mobile phosphorus in Lake Erken sediment. Water Research, 2000, 34(7) : 2037-2042. DOI: 10. 1016/S0043-1354( 99) 00375-9.

[19] Editorial board of water and wastewater monitor the analytical method, State Environmental Protection Administration ed. Water and wastewater monitor the analytical method (3rd edition). Beijing: China Environmental Science Press, 1997. [ 国家环境保护总局《水和废水监测分析方法》编委会. 水和废水监测分析方法(第三版). 北京: 中国环境科学出 版社, 1997.]

[20] He Wei, Shang Jingge, Zhou Qilin et al. Determination of appropriate-ecological sediment dredging depth in Lake Dianshan, China. J Lake Sci, 2013, 25(4) : 471-477. DOI : 10.18307/2013.0403. [何伟, 商景阁, 周麒麟等.淀山湖底泥 生态疏浚适宜深度判定分析. 湖泊科学, 2013, 25(4) : 471-477.]

[21] Hou Jun, Wang Chao, Wang Peifang et al. Temporal variability and spatial distribution of granulometric composition of surface sediments and classification in Taihu Lake. Journal of Hohai University: Natural Sciences, 2013, 41(2) : 114-119. [侯俊, 王超, 王沛芳等. 太湖表层沉积物粒度组成时空分布特征及分类命名. 河海大学学报: 自然科学版, 2013, 41(2) : 114-119.]

[22] Wang Shengrui, Zhao Haichao, Zhou Xiaoning et al. Study on the organic matter, total nitrogen and phosphorus form distribution of different particle size fractions in the sediments from Wuli Lake and Gonghu Lake. Research of Environmental Sciences, 2004, 17 (S1) : 11-14. DOI: 10.13198/j.res.2004.s1.13.wangshr.003. [王圣瑞, 赵海超, 周小宁等. 五里湖 与贡湖不同粒径沉积物中有机质、总氮和磷形态分布研究. 环境科学研究, 2004, 17(S1) : 11-14.

[23] Shi Jing, Zu Xiaojing, Zhang Naiming et al. Sediment phosphorus form, space distribution characteristic and influencing factor of Cao Hai in Dian Lake, Yunnan, China. China Environmental Science, 2013, 33(10): 1808-1813. [史静, 沮晓 静, 张乃明等. 滇池草海沉积物磷形态、空间分布特征及影响因素. 中国环境科学, 2013, 33(10): 1808-1813.]

[24] He Huijun, Yu Zhigang, Yao Qingzhen et al. Distribution of phosphorus in sediments from the Changjiang Estuary and its adjacent sea. Acta Oceanologica Sinica, 2009, 31(5) : 19-30. [何会军, 于志刚, 姚庆祯等. 长江口及毗邻海区沉积 物中磷的分布特征. 海洋学报, 2009, 31(5): 19-30.]

[25] West K. Pollution control and other measures to protect biodiversity in Lake Tanganyika (RAF/92/G32), funded by the United Nations Development Program/Global Environment Facility, 2000. 